\title{
Religious Nonprofits and the Commercial Manner Test
}

\section{Trevor A. Brown}

The scope and administration of tax benefits for religious organizations have generated great controversy in the courts, ${ }^{1}$ the legislature, ${ }^{2}$ and the academic literature. ${ }^{3}$ This Note attempts to clarify the policy rationale underlying the religious exemption from corporate income tax and then uses this rationale to evaluate one particular test for tax exemption under Internal Revenue Code (I.R.C.) section 501(c)(3), the commercial manner test. The commercial manner test allows exemption only when an organization does not exhibit commercial characteristics. ${ }^{5}$

Section I locates the commercial manner test in the existing statutory and regulatory framework. Section II presents a theoretical framework for the religious exemption and draws two conclusions. First, religious organizations are exempt from taxation because of the benefits they confer on society. Second, because of potential problems of tax abuse and difficulties in observing and measuring these benefits, exemption must be confined to nonprofit organizations.

This analytic framework is used, in Section III, to evaluate the commercial manner test. Three observations are made. The fact that a religious organization is operating in a commercial manner does not necessarily indicate that it is conferring less benefit on society. In addition, the commercial characteristics that appear in some religious organizations may simply represent an efficient means of operation. However, some

1. E.g., Walz v. Tax Comm'n of the City of N.Y., 397 U.S. 664 (1970) (unsuccessful establishment clause challenge to exemption of church property from taxation).

2. See, e.g., Schwarz, Limiting Religious Tax Exemptions: When Should the Church Render Unto Caesar?, 29 U. FLA. L. REv. 50, 64-67 (1976) (reviewing legislative difficulties in determining scape of church exemption from unrelated business income tax provisions).

3. E.g., Schachner, Religion and the Public Treasury After Taxation with Representation of Washington, Mueller and Bob Jones, 1984 UTAH L. REv. 275 (criticizing current law as encouraging dependence of religious organizations on government and government control of religion).

4. I.R.C. \$ 501(c)(3) (1989).

5. The Internal Revenue Service (IRS) and the courts apply the commercial manner test in essentially the same way. Because courts' refinements of the test ultimately have determined IRS practice, this Note generally refers to court actions when describing the commercial manner test.

In the religious context, the commercial manner of operation inquiry arises most frequently in relation to publishing companies. Zelenak, Serving Two Masters: Commercial Hues and Tax Exempt Organizations, 8 U. Puget Sound L. REv. 1, 7 (1984). Religious, nonprofit, tax-exempt publishing houses often operate in ways remarkably similar to their for-profit counterparts. See, e.g., Presbyterian \& Reformed Publishing Co. v. Commissioner, 79 T.C. 1070 (1981), rev'd, 743 F.2d 148 (3d Cir. 1984) (large religious publishing house maintains $\S 501$ (c)(3) status). 
commercial characteristics do indicate an increased probability that an organization is actually being operated to enrich insiders and so should not be granted tax-exempt status as a nonprofit.

In light of these observations, Section IV concludes that the commercial manner test is too broad to serve as an independent test for tax exemption. Indeed it should be abandoned entirely by the courts. However, the IRS should use those factors of the commercial manner test that indicate increased probability that an organization is being operated to enrich insiders to assist in determining when a full investigation of a religious organization's finances is necessary. Because the factors of the commercial manner test are general characteristics of organizational operation, obtaining information necessary to determine whether these factors exist is not as intrusive as a direct financial investigation. Thus, by engaging in a two-step process where a modified commercial manner test is applied before a full financial investigation is made, the IRS would be able to identify religious organizations for which a full investigation is not necessary, and so further the government's objective of minimal intrusion into religious affairs. ${ }^{B}$

\section{Current Legal Structure}

An organization must meet four requirements to qualify for tax exemption under I.R.C. section 501(c)(3). First, an organization must be organized and operated exclusively for one of eight exempt purposes: religious, charitable, scientific, testing for public safety, literary, educational, fostering amateur sports, or preventing cruelty to children or animals. Second, the organization's net earnings must not inure to the benefit of any private shareholder or individual. Third, an organization must not engage in substantial political activity. ${ }^{7}$ Fourth, an organization must not engage in activities violative of established public policy. ${ }^{8}$

This Note focuses on the first two requirements. In evaluating whether an organization meets the first requirement-operation for exclusively exempt purposes-the courts and the IRS look for, among other things, the existence of a substantial commercial purpose evidenced by a commercial manner of operation. If a nonprofit strongly demonstrates practices characteristic of for-profit firms, courts will find that the organization is motivated by a substantial commercial purpose. A finding of substantial commercial purpose results in a denial of exemption, despite the existence of an exempt purpose that is furthered by the activity conducted in a commercial manner. ${ }^{9}$

6. See infra text accompanying notes 82-85.

7. I.R.C. § 501(c)(3) (1989).

8. Bob Jones Univ. v. United States, 461 U.S. 574 (1983).

9. See, e.g., Incorporated Trustees of the Gospel Worker Soc'y v. United States, 510 F. Supp. 374 (D.D.C. 1981), affd mem., 672 F.2d 894 (D.C. Cir. 1981), cert. denied, 456 U.S. 944 (1982). 
The second requirement for tax exemption under section 501(c)(3), the ban against private inurement, prohibits enrichment of those persons closely associated with a nonprofit organization. Reasonable payment for goods or services is not private inurement and does not disqualify an organization from receiving section 501(c)(3) status on the grounds that it serves private interests. ${ }^{10}$ Salaries; other cash compensation such as dividends, royalties, or "debt repayment"; and in-kind compensation are evaluated by a reasonableness standard. Where the total of these benefits exceeds reasonable compensation for services rendered, private inurement or purpose to enrich private individuals is inferred. ${ }^{11}$

\section{The Rationale for Exempting NonProfit Religious ORGANIZATIONS FROM TAXATION}

\section{A. Public Benefit}

The dominant rationale for exempting an organization from taxation is that the organization confers benefits on society as a whole. ${ }^{12}$ The organization's activities do not benefit only those who operate it or those to whom it provides services. Since the benefits to the individuals purchasing

Though the literal language of $\S 501$ (c)(3) suggests that any nonexempt purpose precludes an organization from maintaining exempt status, courts have not taken a hard-line position on this issue. Some courts hold that a substantial commercial purpose results in a denial of exemption regardless of the extent or nature of the exempt purpose. Other courts inquire whether the commercial or exempt purpose is primary and award tax status accordingly. For a discussion and review of cases, see Marx, An Analysis of Presbyterian \& Reformed Publishing Company v. Commissioner, 30 CarH. Law. $134,141-43$ (1986). This difference is immaterial to the analysis of this Note.

10. Founding Church of Scientology v. United States, 412 F.2d 1197, 1200 (Ct. Cl. 1969), cert. denied, 397 U.S. 1009 (1970).

11. Sit Church of Scientology of Cal. v. Commissioner, 823 F.2d 1310 (9th Cir. 1987) (finding private inurement under reasonableness standard), cert. denied, 486 U.S. 1015 (1988); Founding Church of Scikntolog;, 412 F.2d at 1200-02. Compensation of a controlling member of a nonprofit based on a percentage of gross revenues may pass the reasonableness inquiry, World Family Corp. $v$. Commissioner, 81 T.C. 958 (1983), but such compensation schemes will be closely scrutinized. $C f$. People of God Community v. Commissioner, 75 T.C. 127 (1980) (exemption denied to church where minister compensated by variable percentage of gross receipts).

12. Bab Jones Uniz., 461 U.S. at 588-92; see also Regan v. Taxation with Representation of Wash., 461 U.S. 540, 544 (1983) (tax exemption and tax deductibility are subsidies administered through tax system to organizations whose activities promote public welfare).

Commentators have proposed tax base defining rationales, as an alternative to the public benefit/ subsidy rationale, for the favorable tax treatment of nonprofits. Tax base defining rationales for tax exemption argue that the exemption of nonprofit organizations from taxation is neither a special privilege nor a hidden subsidy. Rather, taxation of nonprofits is inconsistent with a tax system whose fundamental goal is to tax activities carried on to make a profit. The most notable effort is by Bittker and Radhert who outline both the difficulties of defining the concept of taxable income and the difficulties of determining an appropriate tax rate based on ability to pay for public benefit organizations like religious nonprofits. Bittker \& Radhert, The Exemption of Nonprofit Organizations from Fedcral Income Taxation, 85 YALE L.J. 299 (1976); see also Simon, The Tax Treatment of Nonprofit Orgamzations: A Recieu of Federal and Stale Policies, in The NonPRofit Sector: A Research HANDBOOK 67, 73-75 (Powell ed. 1987) (summarizing tax base defining rationales). But $c f$. Hansmann, The Rationale for Exempling Nonprofit Organizations from Corporate Income Taxalion, 91 YALE L.J. 54 (1981) (criticizing tax base defining rationales and explaining federal income tax exemption of nonprofits as a way of compensating nonprofits for difficulties of capital formation created by prohibition against private inurement). 
and selling services do not reflect the total benefits resulting from an activity, a less than socially optimal level of the activity will occur. Hence, a government subsidy such as tax exemption is necessary to raise the level of an activity creating significant beneficial externalities. ${ }^{13}$

Congress grants section 501(c)(3) status to organizations that it believes convey these significant beneficial externalities. The government forgoes tax revenue to encourage production of the public benefits these organizations convey. ${ }^{14}$ The Supreme Court has held that the public benefits conferred by religious organizations are a "beneficial and stabilizing influence in community life"1s and encouragement of diversified views and perspectives which contributes to a vigorous, pluralistic society. ${ }^{16}$

\section{B. Why Not Exempt Religious For-Profits?}

Although the Supreme Court has adopted a subsidy rationale for tax exemption based on the public benefits nonprofit religious organizations convey, commentators have criticized this theory on the grounds that it argues equally for exemption of for-profit firms that provide the same services as nonprofits. According to these commentators, a reasonably competitive market for services that convey substantial beneficial externalities would result in most of the subsidy being used to produce these services. ${ }^{17}$ Competition would prevent the owners of for-profits from appropriating part or all of the subsidy in the form of higher profits. ${ }^{18}$

13. Simon, supra note 12 , at 76 . Use of the word "subsidy" does not imply that nonprofit organizations are the undeserving beneficiaries of government largess. Rather, a lessened tax burden (or some other form of subsidy) is the correct economic treatment of organizations which produce public benefits.

14. Bob Jones Univ., 461 U.S. at 588-92. Many activities have beneficial externalities. Food, which is generally considered a private good which benefits the one who consumes it, also conveys beneficial externalities on those who enjoy seeing others well fed. Classification as an organization listed in $\S 501(\mathrm{c})(3)$ reflects a legislative judgment that the beneficial externalities provided by an organization are great enough to justify subsidization. See Hansmann, supra note 12, at 66 .

15. Walz v. Tax Comm'n of the City of N.Y., 397 U.S. 664, 673 (1970).

16. Walz, 397 U.S. at 689 (Brennan, J., concurring).

17. In less competitive markets, the revenues foregone by the Government may be used to enrich the owners of for-profits instead of being used to increase activities with significant beneficial externalities. Thus, in less competitive markets, the subsidy of tax exemption must be confined to nonprofits. H. Hansmann, Unfair Competition and the Unrelated Business Income Tax 20 n.37 (Aug. 1988) (unpublished manuscript on file with author).

18. A subsidy would reduce the marginal cost of production. As each firm attempted to maximize profits by setting price equal to marginal cost, the subsidy would be passed on to consumers in the form of lower prices. Hansmann, supra note 12, at 67 . The primary area in which religious organizations currently appear to operate in competitive markets is religious publishing. Tax exempt, religious, nonprofit publishers print religious books similar or identical to those produced by some forprofit publishers. See supra note 5. The issue may also arise in other contexts, such as doing genealogical research necessary to the performance of religious ordinances. Rev. Rul. 71-580, 1971-2 C.B. 235 (organization financed by membership fees, which researches genealogical information so that rites may be performed for dead relatives, qualifies for $\S 501$ (c)(3) status although genealogical research may not ordinarily be for exempt purposes). 


\section{Renaming to Gain Tax Advantages}

Even if some religious organizations operate in competitive markets, there is a powerful rationale for confining tax exemption to religious nonprofits-that is, those religious organizations that do not enrich the people who operate them. Although it is difficult to define religion, it seems clear that the goals of the religious exemption-encouraging activities which have a beneficial and stabilizing influence on society and contribute to pluralism 19 -are not furthered by organizations renaming activities "religious" to increase profits to owners. ${ }^{20}$ If "religious" for-profit organizations were allowed to claim 501(c)(3) status, the IRS and the courts would face the difficult task of determining which of these for-profit organizations were in fact religious, and which were merely calling themselves religious to gain the subsidy of tax exemption to enrich owners. ${ }^{21}$ The prohibition against private inurement allows the IRS and the courts to avoid an inquiry into religiosity or sincerity in these cases and turn instead to a determination of whether an organization is nonprofit. ${ }^{22}$

The problem of renaming is substantial. Despite the prohibitions against private inurement and private benefit, which undoubtedly deter much renaming, the Tax Court is inundated with cases of renaming to enrich owners. ${ }^{23}$ These cases are not easily decided. It is practically difficult and constitutionally problematic to separate what is "sincerely religious," and hence deserving of tax exemption, from what is merely tax motivated renaming. ${ }^{24}$ Courts have found few activities which they consistently view as evidence of a substantial nonexempt purpose, and hence implicitly unreligious, resulting in a denial of section 501(c)(3) status.

19. Sep supra notes $12-16$ and accompanying text.

20. Giving advice on how to reduce tax liability is a nonexempt purpose. National Ass'n of Am. Churches v. Commissioner, 82 T.C. 18 (1984); Ecclesiastical Order of the ISM of AM v. Commissioner, 80 T.C. 833 (1983), affd, 740 F.2d 967 (6th Cir. 1984); Christian Stewardship Assistance v. Cornmissioner, 70 T.C. 1037 (1978).

21. In theory all for-profits will engage in renaming resulting in entire industries being subsidized (assuming for-profits have no motivation to abstain from calling their activities religious). In a competitive market these subsidies will be passed through to purchasers resulting in no net profits to the owners of for-profits. However, renaming will still accur as each for-profit firm seeks a competitive advantage. In addition, actual profits may be obtained due to organizations obtaining information about the availability of a subsidy at different times.

22. The private inurement constraint does not, however, prevent renaming to gain tax advantages to increase an organization's output of products. In these situations the government must make the hard decision of what is religious and what is not.

23. B. Hopkins, The Law of Tax-Exempt Organizations 194-98 (1987). Avoidance of the corporate income tax is not the only reason firms would engage in renaming. Most states grant property tax exemption to $\$ 501$ (c)(3) organizations. Simon, supra note 12, at 72 . Consequently there is an incentive for organizations not subject to the corporate income tax to attempt to qualify for $\$ 501(c)(3)$ status as religious organizations.

24. The courts and the IRS cannot disallow an organization's tax-exempt status on the grounds that the beliefs on which it rests are inherently unreligious, but only on the grounds that the alleged beliefs are not sincerely held. See Hernandez v. Commissioner, 109 S. Ct. 2136, 2146 (1989) (religious benefit standard for which money transfers qualify for charitable deduction is unworkable because tax payers' beliefs may only be questioned as to sincerity not inherent religiosity). 
The history of the Universal Life Church is illustrative. Upon first consideration, the courts refused to find that the Universal Life Church's extensive practice of granting church charters, ordaining ministers, and issuing Honorary Doctor of Divinity certificates through the mail for a suggested twenty dollar free-will offering were evidences of a nonexempt purpose. The Universal Life Church had no traditional doctrine; its members and pastor only believed that everyone had a right to his or her own beliefs. $^{25}$ However, the court reasoned:

The fact that the plaintiff distributed ministers' credentials and Honorary Doctor of Divinity certificates is of no moment. Such activity may be analogized to mass conversions at a typical revival or religious crusade. Neither this Court, nor any branch of this Government, will consider the merits or fallacies of a religion. Nor will the Court compare the beliefs, dogmas, and practices of a newly organized religion with those of an older, more established religion. Nor will the Court praise or condemn a religion, however excellent or fanatical or preposterous it may seem. Were the Court to do so it would impinge upon the guarantees of the First Amendment. ${ }^{26}$

It was not until years later, when the IRS denied the Universal Life Church's exemption on the narrow grounds that a substantial part of its activities were directed at supplying tax advice, an established nonexempt purpose, that denial of exemption was upheld. ${ }^{27}$

\section{Weighing the Costs and Benefits of the Private Inurement Constraint}

The important question in articulating a rationale for the private inurement constraint is whether it solves more problems than it creates. The private inurement restriction is not costless. It involves detailed and extensive factual inquiry into every use of an organization's funds. However, when compared with the difficulties involved in defining religion and religious activities, illustrated by the cases dealing with the Universal Life Church, a private inurement investigation appears significantly less difficult than supporting a claim that a particular organization is not truly religious. IRS practice reflects this judgment. Usually the IRS does not disqualify an organization on the grounds that it is not religious where it appears that renaming to enrich owners is occurring. ${ }^{28}$ Rather, it disqual-

25. Universal Life Church, Inc. v. United States, 372 F. Supp. 770 (E.D. Cal. 1974).

26. Id. at 776 .

27. Universal Life Church, Inc. v. United States, 13 Gl. Ct. 567 (1987), affd, 862 F.2d 321 (Fed. Cir. 1988). After first seeking and failing to obtain summary judgment against the Universal Life Church on the grounds of private inurement, the IRS successfully sought summary judgment against the Universal Life Church on the grounds described in the text. Id. at 580.

28. See Slye, Rendering unto Caesar: Defining "Religion" for Purpose of Administering Religion-Baspd Tax Exemptions, 6 Harv. J.L. \& PUB. POL'Y 219, 250, 280 (1983). 
ifies the organization on the grounds of private inurement and private benefit even though the facts of a case might well support a finding that the alleged religious beliefs were not sincerely held or that the organization was not engaging in activities furthering religious purposes. ${ }^{29}$

In addition, though the private inurement inquiry involves an intrusive analysis of a religious organization's financial operations, it is simpler than evaluating an organization's activities to determine if they are religious. ${ }^{30}$ Simple criteria for defining the scope of religious exemption are preferable in light of the importance of maintaining separation between church and state. "As a general rule, the more complicated the basis of classification for exemption, the greater the danger of involving the Government in entangling inquiries." 31 Entanglement of the government with religious institutions may result in government interfering with the independence of religious institutions, religious institutions may gain undue access to and exercise control over the monitoring government agency, or the potential for political divisions along religious lines may increase. ${ }^{32}$

Although the prohibition against private inurement makes administration of tax exemption less difficult and less entangling, denial of exemption to for-profit firms may unfairly treat for-profit providers of religion or religion-related goods and services which provide beneficial externalities as great as those produced by nonprofits and which are in competition with tax-exempt nonprofits. As tax-exempt nonprofits use the subsidy of tax exemption to decrease the industry price, the profits of these for-profit organizations are reduced. Consequently, these for-profit religious organizations bear a disproportionate share of the societal costs of tax exemption.

However, true unfairness to for-profit firms occurs in few situations. First, religious nonprofits control only a small proportion-less than one percent-of the nation's economic resources. Many of these organizations

29. Id. at 270, 291-92; see, e.g., Levy Family Tribe Found., Inc. v. Commissioner, 69 T.C. 615 (1978) (exemption denied to family controlled organization which believed that each stamp traded represented a living soul and a link to religious activity carried on by ancestors, based on finding of private inurement); Basic Bible Church v. Commissioner, 74 T.C. 846 (1980) (exemption denied to organization claiming religious purpose, supported by founder and paying a substantial portion of founder's living expenses, based on finding of private benefit), aff $d$ sub nom., Grazow v. Commissioner, 739 F.2d 265 (1984); Bubbling Well Church of Universal Love v. Commissioner, 74 T.C. 531 (1980) (exemption denied to organization, formed to disseminate belief in benevolent Supreme Being, which paid substantial monies to founder and was supported by founder, absent showing of adequate services rendered in exchange for monies).

30. An established and coherent body of law exists to determine what constitutes private inurement. Sep supra note 11 and accompanying text. In contrast, Federal tax law lacks a coherent and workable definition of the term "religious." B. HopkINS, supra note 23, at 194.

31. Church of Scientology of Cal. v. Commissioner, 83 T.C. 381,458 n.53 (1984), affd, 823 F.2d 1310 (9th Cir. 1987). Some commentators see minimization of involvement between religious organizations and the government as the primary justification for religion based tax exemption. E.g., Chisolm, Exempl Organization Adzocacy: Matching the Rules to the Rationales, 63 IND. L.J. 201, 266 (1987).

32. Lynch v. Donnelly, 465 U.S. 668, 688-89 (1984) (O’Connor, J., concurring). 
are churches whose primary activities do not meaningfully compete with for-profit organizations. Thus only those for-profit religious organizations that compete with a subset of a very small proportion of the economy bear a disproportionate share of the costs of the religious tax exemption. ${ }^{33}$ Second, the disproportionate burden on for-profit organizations in competition with religious nonprofits may be called unfair only where exit from an industry is costly, and where nonprofit entry into an industry is unforeseen. If exit from an industry is not costly, then for-profit organizations whose profits are being reduced by competition with tax exempt nonprofits can simply leave the industry and make the market rate of return in another sector of the economy. Likewise, if tax-exempt nonprofit organizations are already involved in a particular business before a forprofit enters the industry, or if the entry of nonprofits is foreseen, the forprofit organization voluntarily assumes the lower rate of return caused by the presence of nonprofits. Thus this lower rate of return is not unfair. ${ }^{34}$

In sum, the truly unfair costs to this relatively small group of organizations appear to be outweighed by the decreased administrative costs and the lessened government involvement in religious affairs made possible by the private inurement constraint. ${ }^{35}$

\section{The Limits of the Argument}

This rationale for non-profit tax exemption does not apply to all section 501(c)(3) organizations. The justification for the private inurement constraint in the religious context is that the costs of administering this standard in conjunction with a standard focusing on beneficial externalities

33. Estimates based on 1984 statistics conclude that $\S 501(\mathrm{c})(3)$ and $\S 501(\mathrm{c})(4)$ nonprofits account for only $5.6 \%$ of the national income. Religious organizations account for almost $12 \%$ of this figure. B. HopkiNs, supra note 23 , at 18-22. In addition, $\$ 501(\mathrm{c})(3)$ and $\S 501(\mathrm{c})(4)$ organizations account for only $4.2 \%$ of total entities in the United States compared with $94 \%$ for the business sector. Id.

34. Rose-Ackerman, Unfair Competition and Corporate Income Taxation, 34 STAN. L. REv. 1017, 1019-21, 1025 (1982).

In addition to fairness considerations there is an efficiency concern. If nonprofit religious organizations are less efficient at producing religious goods and services than are for-profit religious organizations, a net efficiency loss results from confining a production subsidy to nonprofit organizations. Because nonprofit organizations have no owners seeking to maximize revenues, arguably they may not be as effective at minimizing costs as are for-profit firms. Conversely, one may argue that in the religious context the ideological motivation of firm managers will provide appropriate cost minimizing incentives. In addition, nonprofit organizations may be able to harness resources, such as volunteer workers, that would not be available to a for-profit firm. The relative efficiency of religious nonprofits and for-profits is a complicated empirical question and is beyond the scope of this Note. Cf. Frech, The Property Rights Theory of the Firm: Empirical Results from a Natural Experiment, $84 \mathrm{~J}$. Pol. EcoN. 143 (1976) (suggesting nonprofit insurance companies are less efficient than for-profit insurance companies).

35. See supra notes $28-34$ and accompanying text.

The possibility of granting tax benefits to for-profits is limited to competitive industries. See supra note 17. Therefore, a significant additional cost to elimination of the private inurement constraint for religious organizations in competitive markets is differentiating between more and less competitive markets for religious services. 
are lower than the costs of administering a standard that focuses exclusively on beneficial externalities. This argument rests on the premise that determining whether an organization is religious, and so produces beneficial externalities, is difficult and costly. ${ }^{36}$ It is not clear that determining whether non-religious section 501(c)(3) organizations produce beneficial externalities (i.e. are truly educational, scientific, etc.) is as costly. Treasury regulations define some of the exempt purposes of non-religious section 501(c)(3) organizations, making identification of organizations in these categories easier than in the religious category. ${ }^{37}$ This may explain why many for-profits engaging in tax-motivated renaming attempt to qualify for section 501(c)(3) status under the religious exemption..$^{\mathbf{3 8}}$ In addition, only the religious exemption presents the possibility of infringements on the constitutional norms against entanglement of government and religion ${ }^{30}$ free religious exercise, ${ }^{40}$ and government establishment of religion. ${ }^{41}$ It appears then, that determining whether non-religious section 501(c)(3) organizations produce beneficial externalities is significantly less costly than this determination is in the religious context. Thus in the nonreligious context, where categorization is easier and tax abusers are more easily recognized, a standard that focuses exclusively on beneficial externalities and does not prohibit private inurement may be appropriate.

\section{Evaluation of the Commercial Manner Test}

The previous section developed a public benefit rationale for religious exemption, emphasizing the need to prevent private inurement. This section evaluates the commercial manner test to see how it helps identify organizations that should not enjoy favored tax status: those organizations

36. See supra notes 20-27 and accompanying text.

37. Treas. Reg. $\S 1.501$ (c)(3)-1(d)(2) to (5) (as amended in 1976) (defining what is charitable, educational, testing for public safety, and scientific). Courts and the IRS explicitly face the issue of deciding whether an organization qualifies for $\$ 501$ (c)(3) status under one of the non-religious categories. This contrasts with avoiding the determination of whether an organization is religious. See, e.g., National Alliance v. United States, 710 F.2d 868 (D.C. Cir. 1983) (publications not educational because not supported by reasoned development).

38. See Cerny \& Fontenrose, Administering Exempt Organization Tax Lau: Confronting Commercialization, the Constitution, and Campaigns, N.Y.U. FIfTEENTH Biennial Conf. ON TaX Planning for the Charitable Sector $\$ \S 1.02(3), 1.03$ (1987). Another reason that the religious cxemption may be so attractive to organizations motivated by tax avoidance is the collection of tax advantages that churches, a subcategory of religious organizations, enjoy. Id.; see infra notes 81-85 and accompanying text for church tax advantages.

39. SPe, e.g., Walz v. Tax Comm'n of the City of N.Y., 397 U.S. 664, 676 (1970) (tax exemption minimizes involvement between church and state and so "tends to compliment [sic] and reinforce the desired separation insulating each from the other"). Entanglement claims arise under the establishment clause. Entanglement is listed separately here because of the prominence entanglement issues are given in religious tax exemption cases.

40. See, e.g., United States v. Lee, 455 U.S. 252 (1982) (collection of Social Security taxes contrary to Amish belief justified upon showing of compelling governmental interest).

41. See, e.g., Larson v. Valente, 456 U.S. 228 (1982) (differential burdens placed upon religious organizations because of their fund-raising practices must be "closely fitted" to achieve compelling state ends). 
that do not generate substantial benefits for society as a whole, or those organizations in which private inurement is occurring.

When applying the commercial manner test, courts and the IRS examine nonprofits for practices characteristic of for-profit firms. If enough of these for-profit practices are strongly demonstrated, section 501(c)(3) status is denied on the grounds that the organization in question has a substantial commercial purpose. ${ }^{42}$ Although courts have not clearly articulated the rationale underlying the commercial manner test, they seem to implicitly hold that the policy objectives of tax exemption are not furthered by exempting organizations whose activities are conducted in a commercial manner. The Third Circuit summarized this general approach:

[C]ourts have focused on the manner in which activities themselves are carried on, implicitly reasoning that an end can be inferred from the chosen means. If, for example, an organization's management decisions replicate those of commercial enterprises, it is a fair inference that at least one purpose is commercial, and hence nonexempt. And if this nonexempt goal is substantial, tax exempt status must be denied. ${ }^{43}$

In the religious context, the commercial manner test is applied most frequently to nonprofit, tax-exempt religious publishers. Often religious publishers sell most of their publications for prices that cover their costs and generally operate in ways similar to for-profit publishers. ${ }^{44}$ However, the commercial manner test has also been applied to other religious organizations that advance religious purposes in unconventional ways. One example is the Golden Rule Church Association which operated various businesses as religious training centers for living out the "golden rule" in daily life. ${ }^{45} \mathrm{~A}$ recent and vigorously contested application of the commercial manner test occurred in Church of Scientology of California v. Commissioner. ${ }^{46}$ The Tax Court revoked the Church's exemption because, among other things, its activities, which primarily consisted of providing

42. See supra note 9 and accompanying text.

43. Presbyterian \& Reformed Publishing Co. v. Commissioner, 743 F.2d 148, 155 (3d Cir. 1984).

44. Sep, e.g., Presbyterian \& Reformed Publishing Co. v. Commissioner 79 T.C. 1070 (1981) (exemption revaked), rev'd., 743 F.2d 148 (noting no private inurement); Incorporated Trustees of the Gospel Worker Soc'y v. United States, 510 F.Supp. 374 (D.D.C. 1981) (exemption revoked); Christian Manner Int'l, Inc. v. Commissioner, 71 T.C. 661 (1979) (exemption denied); Pulpit Resource v. Commissioner, 70 T.C. 594 (1978) (exemption granted).

45. Golden Rule Church Ass'n v. Commissioner, 41 T.C. 719 (1964) (exemption granted to religious organization operating carpentry shops, laundry, hotel, sawmill, nursery, and ranch as religious training centers for living golden rule in daily life).

46. 83 T.C. 381 (1984), aff d on other grounds, 823 F.2d 1310 (9th Cir. 1987) (affirming revocation on finding of private inurement). 
one-to-one religious services for a fee, were conducted in a commercial manner. ${ }^{47}$

Courts and the IRS look for the following characteristics in determining commercial purpose evidenced by commercial manner of operation: 1) sales of goods and services; 2) profit making and accumulation of profits; 3) competition with for-profit firms; 4) extensive and successful expansion efforts; 5) formal contractual arrangements; 6) use of paid rather than volunteer workers; and 7) isolation and centralization of organizational control. ${ }^{48}$ The following sections argue that factors one and five are irrelevant to a proper determination of whether an organization should hold section 501(c)(3) status. The other factors, however, indicate increased probability that private inurement is occurring in violation of the statutory prohibition. However, since these factors do not conclusively show that private inurement is occurring, the commercial manner test should act merely as a screening device which triggers a more complete private inurement investigation.

\section{A. Irrelevant Factors}

\section{Sales of Goods and Services}

Courts may be critical of organizations engaging in sales in the religious context because they think that the beneficial externalities religious organizations convey (a beneficial and stabilizing influence in society and encouragement of pluralism) are less when goods and services are sold than when they are paid for by donations. The consistent existence of sales in traditional religious practice rebuts this opinion. ${ }^{49}$ Rather, sales may at certain times be a way of distributing religious goods and services to those who value them most and will not waste them, thus advancing the cause of religion most effectively.

Many Jewish synagogues raise from twenty percent to all of their income through annual dues charged on a per family basis for membership in the local synagogue. For seats on High Holy Days there is often a separate charge that varies with the number and location of seats. Typical seat fees in 1982 ranged from $\$ 200$ to $\$ 2000$. Synagogues also often charge special fees to participate in Passover services and meals. Pew rental is another form of sales, one that has a mainstream Christian history in the United States. The payment of Mass stipends, fees fixed by the

47. The Church of Scientology teaches that to reach spiritual awareness, a person must go through a process called "auditing," which a trained Scientologist, an "auditor," administers for a fee. Id. at 385 .

48. See cases cited supra notes 44-46.

49. See infra text accompanying note 50 . 
Catholic Church for Masses said in the name of or on behalf of the payor, also involves sale of services. ${ }^{50}$

It is doubtful, then, that sales indicate that a religious organization is conveying fewer benefits on society. ${ }^{\mathbf{5 1}}$ Neither is it apparent that sales indicate increased probability of private enrichment. ${ }^{52}$ Rather, sales reflect the considered judgment of religious nonprofit managers that paying the costs of delivering religious goods and services is more efficiently accomplished by sales than donations. Hence, courts have incorrectly considered sales an indicator of when tax exemption should be denied.

\section{Formal Contractual Arrangements}

Contractual arrangements allow for efficient and clear allocation of resources and responsibilities. Religious organizations need to engage in this kind of allocation just as other organizations do. Detailed contractual arrangements are typical of many traditional churches. The United Methodist Church is regulated by The Book of Discipline, ${ }^{53}$ which in addition to setting forth the doctrinal position of the church ${ }^{54}$ specifically delineates the manner in which title to real property is to be held, ${ }^{\text {ss }}$ provides for auditing and bonding of church officers, ${ }^{58}$ regulates the manner in which offerings are to be handled, ${ }^{67}$ provides for specific percentage allocations

50. Hernandez v. Commissioner, 109 S. Ct. 2136, 2150 (1989); Hernandez v. Commissioner, 109 S. Ct. at 2153-55 (O'Connor, J., dissenting); Brief for Petitioner at 18-24, Hernandez v. Commissioner, 109 S. Ct. 2136 (1989) (No. 87-963). In Hernandez the Court found that fixed payments for auditing services offered by the Church of Scientology were not deductible from the payor's income as charitable deductions because these payments were not "gifts." The Court never suggested, however, that the type of payments discussed in the text would make a religious organization less worthy of $\S 501$ (c)(3) status.

51. See also Marx, supra note 9 (arguing that tax exemption of trade or business is consistent with Internal Revenue Code); Blair, Business Actizities of Tax-Exempts and Affiliates, 33 WILliaM \& MARY TAX CoNF. 1, 8 (1987) (unrelated business income tax provisions served as basis for reversing IRS's narrow view of permissible business activities of $\S 501(c)(3)$ organization).

52. Sales and donations are alternative ways to pay for services. Perhaps the most notable recent occurrence of private inurement in a religious organization took place in an organization financed primarily by donations. In the case of the PTL broadcasting ministry, the IRS report recommending revocation of the organization's $\S 501$ (c)(3) status because of private inurement documented approximately $\$ 2.5$ million of excessive compensation to PTL's officers during the years 1981-83. Almost all of these funds were paid to or expended for the benefit of Jim Bakker, the principal officer of PTL, his wife, Tammy Bakker, and their family. IRS REPORT of EXAMINATION-EXEMPT ORGANIZArions, Heritage Village Church and Missionary Fellowship, Inc. 9 (Oct. 25, 1985).

Hansmann's contract failure theory notes that effective monitoring of the quality of services paid for by donations is often more difficult than monitoring the quality of services paid for by sales. This is because the person paying for services and the person receiving services are often not the same when the services are paid for by donations. Hansmann, supra note 12 , at 69 . Conceivably, this could make private inurement more likely in organizations financed by donations because those paying for the services would not be aware that funds were not being used to produce services.

53. The United Methodist Church, The Book of Discipline of the United MethodIST Church (1988).

54. Id. passim.

55. Id. at III 2501-2509.

56. Id. at I 2510 .

57. Id. at I 269.4 . 
of certain offerings to specified programs, ${ }^{68}$ and establishes a structure for determining clergy compensation. ${ }^{58}$ The Presbyterian Church (U.S.A.) is regulated by the Book of Order, a document that clearly allocates many temporal responsibilities and privileges of its suborganizations and members. ${ }^{.0}$

Although formal contractual arrangements are a characteristic of forprofit operation, they indicate nothing about increased probability of private inurement or decreased public benefit. Inclusion of this factor as part of the commercial manner test indicates that courts have become confused regarding the goal of their inquiry. In looking for commercial characteristics in nonprofits, they have seized upon any observable characteristics of for-profit functioning without careful attention to the theory underlying their investigation.

\section{B. Factors Indicating Increased Probability of Private Inurement}

\section{Profit Making and Accumulation of Profits}

Courts and the IRS have a valid reason for looking at the existence and accumulation of profits in determining exemption. These factors indicate increased probability of private inurement. The more profit a nonprofit reaps on sales furthering its religious purpose, the more funds are available to be devoted to private ends. Likewise, as a nonprofit accumulates cash reserves, more funds are available to divert to private ends. ${ }^{61}$ However, pricing at a profit and retaining profits often reflect a considered judgment about how a nonprofit may best further its religious purposes. Funds may be needed to weather financial downturns and to expand operations. $^{62}$

58. Id. at $\pi 274$.

59. Id. at $\Upsilon$ II 717-723.

60. Presbyterian Church (U.S.A.), Book of Order (1988). Examples include id. at § G8.0000 (defining manner in which title to property is to be held and how property is to be allocated in event of church schism); $i d$. at $\$$ G-10.0400 (describing minimum standards of financial procedure); id. at $\$$ G-9.000 (overview of organizational structure and provision for review of action by next higher governing bady).

61. Cf. Incorporated Trustees of the Gospel Worker Soc'y v. United States, 510 F. Supp. 374, 379 (D.D.C. 1981) (increases in salaries associated with accumulation of profits), aff $d$ mem., 672 F.2d 894 (D.C. Cir. 1981), cert. denied, 456 U.S. 944 (1982). Courts should treat organizations financed by sales and those financed by donations similarly in applying this factor. As Hansmann demonstrates, the concept of profit also applies to organizations financed by donations. Donations may be viewed as payments for delivery of services to another and expenses as the cost of delivering a service with the difference being profit (or loss). Hansmann, supra note 12, at 61 .

62. Sep, e.g., Presbyterian \& Reformed Publishing Co. v. Commissioner, 743 F.2d 148, 157-58 (3d Cir. 1984) (accumulation of profits for expansion with finding of no private inurement). Because of the prohibition against private inurement, nonprofits may not raise capital by issuing equity stock. Thus it is important for them to be able to raise capital by accumulating cash reserves. See Hansmann, supra note 12 . 


\section{Competition with For-Profit Firms}

Competition with for-profit firms does not indicate that a religious nonprofit is producing fewer beneficial externalities and so is less deserving of the subsidy of tax exemption. Rather, it raises the question of why the for-profits are not also being subsidized. ${ }^{63}$ However, the costs arising from abusive claims for tax exemption justify denying exemption to for-profits providing religious goods and services in competition with nonprofits. ${ }^{64}$

This analysis supports current legislative treatment of the business activities of nonprofits that advance their exempt function. In 1950 Congress enacted the unrelated business income tax (U.B.I.T.) in response to complaints of competitive disadvantage by for-profits competing with tax exempt organizations. ${ }^{65}$ The U.B.I.T. taxes business activities of nonprofits not substantially related to their exempt function. However, those business activities "substantially related" to an organization's exempt purpose are not taxed. ${ }^{66}$ Nonprofit activities directly accomplishing an exempt purpose and in competition with for-profits maintain tax favored status. ${ }^{67}$

Courts are correct, however, in considering competition with for-profits in evaluating a religious organization's eligibility for exemption. Though competition with for-profit firms does not indicate less need for a subsidy, it does indicate increased probability of private inurement. Activity by forprofits in a sector of the economy indicates that market conditions allow profits to be made and used to enrich owners. Thus, although a nonprofit operating in competition with for-profits may not be enriching its operators, there is clearly a potential for this to occur.

63. The rationale for subsidizing religious organizations through tax exemption, developed at the beginning of this Note, is that they convey substantial beneficial externalities on society. Since the vendors and purchasers of religion do not receive all the benefits resulting from religion a less than optimal production will occur, creating the need for subsidy. See supra text accompanying notes 12-16. The judgment that a less than optimal level of religious activity will be produced by market forces is independent of whether for-profits or nonprofits produce it.

64. See supra text accompanying notes 19-35.

65. I.R.C. $\$ \S 502,511-514$ (1989); Marx, supra note 9, at 139 n.24 (U.B.I.T. enacted because of unfair competition); Zelenak, supra note 5, at 17 (U.B.I.T. enacted because of congressional concern with unfair competition); $c f$. Rose-Ackerman, supra note 34 (arguing that U.B.I.T. creates greater difficulties than it solves).

66. I.R.C. $\$ 513(\mathrm{a})(1989)$.

67. Zelenak, supra note 5, at 17. The legislative history of the Tax Reform Act of 1969, which extended application of U.B.I.T. to certain activities previously considered related to exempt purposes and abolished special treatment of churches which had been exempt from U.B.I.T., also supports this interpretation. "[A] business competing with taxpaying organizations should not be granted an unfair competitive advantage by operating tax free unless the business contributes importantly to an exempt function." H.R. REP. No. 413, 91st Cong., 1st Sess. 44, reprinted in 1969 U.S. Cone ConG. \& ADMIN. News 1645, 1695.

The scope and application of the U.B.I.T. has recently been the subject of congressional discussion. It appears likely that the "substantially related test" will remain the basic standard for application of the U.B.I.T. to a nonprofit's business activity. However, legislation may be enacted that defines more specifically what types of commercial activity are considered related to an organization's exempt purpose. Pickle, Draft Report Describing Recommendations on the Unrelated Business Income Tax, Daily Tax Rep., June 24, 1988, at L-4. 


\section{Extensive and Successful Expansion Efforts}

Aggressive marketing of religion may be the most effective way of disseminating religious beliefs. Rapid expansion may demonstrate that a religion is meeting deeply felt religious needs. Scrutiny of religious organizations on the basis of rapid expansion creates the danger of encouraging a stagnant society where various ideas and creeds preserve a hold on a fixed proportion of the population. ${ }^{88}$ Any factor that scrutinizes a religious organization because of its success must be accepted with caution. However, private inurement is more likely, all else being equal, in an expanding than in a non-expanding nonprofit because a diversion of funds to private ends will be both more noticeable and more morally objectionable if it occurs in a non-expanding nonprofit.

A diversion of funds to private ends in a non-expanding nonprofit will cause service levels to fall from a previously established level. This is a measurable decline. However, although a diversion of funds from an expanding nonprofit will result in slowed expansion, this will not be as noticeable as a decline in service levels because there is no existing benchmark from which to measure decline. Consequently, a diversion of funds to private ends is more likely in an expanding than in a non-expanding nonprofit.

A diversion of funds from a non-expanding nonprofit will result in taking (decreasing) services from those to whom they are already being rendered. A diversion of resources from an expanding nonprofit will only result in not rendering services to people who are not yet recipients of these services (or not rendering more services to those already served). It seems intuitively more objectionable to turn away someone to whom one has been providing religious services than to not begin providing others with these services. Recent work in the economic literature supports the validity of this intuition by demonstrating that mere possession of something increases its value to the possessor. ${ }^{69}$ Thus more harm would be done by cutting off one who is receiving something than by not beginning to supply someone not yet receiving something. ${ }^{70}$ Consequently, there is a greater moral barrier against diverting funds to private ends in a nonexpanding than in an expanding nonprofit. As a result, diversion of funds is more likely in an expanding nonprofit. ${ }^{71}$

68. Presbyterian \& Reformed Publishing Co. v. Commissioner, 743 F.2d 148, 158-59 (3rd Cir.

1984). This discourages rather than encourages pluralism.

69. J. Knetsch, R. Thaler \& D. Kahneman, Experimental Tests of the Endowment Effect and the Coase Theorem (Sept. 1987) (unpublished manuscript on file with author).

70. The intuition described in the text is also supported by more traditional economic concepts. The expected value of new services to new recipients will be discounted by an uncertainty factor (assuming risk aversion). Persons already receiving religious goods or services will be certain of the nature of the services they are receiving and thus have a higher expected value for these services than would new potential recipients.

71. Two kinds of harm are done when a controlling group enriches itself from nonprofit funds. 


\section{Use of Paid Rather Than Volunteer Workers}

Certain activities demand such a large commitment of time and resources that they cannot be effectively done on a volunteer basis. However, courts have a valid reason for considering the absence of volunteer workers in determining eligibility for tax exemption. Volunteer workers provide a check against private inurement built into the structure of a nonprofit organization. Volunteer workers receive no material compensation for their efforts. Their only benefit is derived from advancing an organization's religious purpose. Thus, if funds are used to enrich individuals rather than to advance religious purposes, volunteer workers will protest. In contrast to paid workers, volunteer workers have no material dependency on the nonprofit to deter this protest. Hence, their absence results in increased probability that private inurement will occur.

\section{Isolation and Centralization of Organizational Control}

A small group of individuals may be just as motivated by religious purposes as a large group, and control may be centralized to streamline the decision-making process. However, when a small group of individuals assumes control of an organization's resources, private inurement is more likely than when these resources are controlled by a large group of decision makers. This is because the potential benefits to each member of a small group from using nonprofit funds to enrich the controlling group are greater than they are to each member of a large group. As a result, each person in a small group has a greater incentive to circumvent the prohibition against private inurement. ${ }^{72}$ In addition, the smaller the controlling group the smaller the chance that someone will accidentally disclose that private inurement is occurring. ${ }^{73}$ Finally, the larger the group

First, the government treasury is depleted because the subsidy of tax exemption is diverted to private ends. Second, the beneficiaries of nonprofit activity are deprived of benefits. The second kind of harm is perceived as being greater in a non-expanding nonprofit. This makes it less likely that private inurement will occur. Thus, although less private inurement may occur in a non-expanding nonprofit, the aggregate harm done to beneficiaries of nonprofit activity may be the same in expanding and nonexpanding nonprofits. This is because private inurement, though occurring less in non-expanding nonprofits, will cause more harm to the beneficiaries of nonprofit activity when it does occur.

However, the impact on the government treasury will be less severe in non-expanding nonprofits. This is because less private inurement will occur in non-expanding nonprofits, because those enriching themselves will be aware of the greater harm done to the beneficiaries of nonprofit activity. The existence of the first kind of harm, depletion of the government treasury, will not reduce the likelihood of private inurement because those enriching themselves from nonprofit funds will view this depletion as affecting an impersonal institution, not as hurting real people. Thus private inurement is more likely in an expanding nonprofit, and so greater depletion of the government treasury results.

72. Holding resources constant, the fewer people who receive part of the resources, the more each person will receive. If each person must incur fixed costs to receive a part of the resources, she or he is more likely to incur the costs as the benefits increase.

73. If we assume that there is some probability that each controlling member of a nonprofit will unintentionally disclose that the controlling group is enriching itself from nonprofit funds, the probability of disclosure increases as the group gets larger. As probability of disclosure increases, there is less need for government concern that private inurement will go undetected. 
that must coordinate to effect private inurement, the more likely it is that there will be an individual with a moral level sufficiently high to withhold cooperation and so prevent private enrichment from occurring. ${ }^{74}$

\section{Conclusions about the Commercial Manner Test}

The analysis of the previous pages demonstrates that the only useful purpose the commercial manner test serves in identifying which religious organizations should be eligible for tax exemption is to detect an increased probability of private inurement. ${ }^{75}$ However, each of the five factors indicating this increased probability may also merely reflect wise decisions about how best to advance an organization's exempt purposes. In addition, private inurement may occur when some of these factors are absent. Further, there is already a direct statutory prohibition against private inurement and the courts have developed a jurisprudence to evaluate whether this is occurring. ${ }^{78}$

\section{A PROPOSAL FOR REFORM}

In light of this analysis courts should abandon the commercial manner test entirely. By the time a religious organization's tax status is litigated in court, the IRS will have gathered information more probative of whether private inurement is occurring than that given by the factors of the commercial manner test. ${ }^{77}$

However, with some qualifications the five factors of the commercial manner test that indicate increased probability of private inurement may be incorporated into the regulatory procedure used by the IRS to develop

74. Individuals have different propensities to break laws. This may be nothing more than a reflection of disparate needs or environments, but the fact remains. The larger a controlling group is (assuming random distribution of individuals with high propensities to obey law), the more likely it is that the controlling group will include an individual with a high propensity to obey law who will not cooperate in a private inurement scheme. Thus the smaller the controlling group, the greater the probability that this self-checking mechanism will not exist and consequently private inurement will occur.

75. This interpretation of the commercial manner test, which is based on $\S 501$ (c)(3)'s requirement that an organization be operated exclusively for exempt purposes, makes the private inurement requirement a subset of the exclusive operation requirement. This reading is supported by the Treasury Regulations interpreting § 501(c)(3):

An organization is not organized or operated exclusively for one or more of the purposes specified in subdivision (i) of this subparagraph unless it serves a public rather than a private interest. Thus, to meet the requirement of this subdivision, it is necessary for an organization to establish that it is not organized or operated for the benefit of private interests such as designated individuals, the creator or his family, shareholders of the organization, or persons controlled, directly or indirectly, by such private interests.

Treas. Reg. $\$ 1.501$ (c)(3)-1(d)(1)(ii) (as amended in 1976); see text accompanying note 7 (enumerating purposes); see also Bubbling Well Church of Universal Love, Inc. v. Commissioner, 74 T.C. 531 , 535 (1980) (reading private inurement and private benefit synonymously), aff d, 670 F.2d 104 (9th Cir. 1981); Slye, supra note 28, at 267 (practical effect of private inurement test is to insure that organization serves public rather than private purpose).

76. See supra notes 10-11 and accompanying text.

77. See infra note 87 and accompanying text. 
a less intrusive monitoring structure. First, it is important to note that these factors should not be determinative in deciding whether exemption should be granted because they merely indicate increased probability of private inurement, not certainty. ${ }^{\mathbf{7 8}}$ Second, when it is clear that private inurement is not occurring, inquiry into commercial manner should cease because detecting private inurement is the sole legitimate function of the commercial manner test. ${ }^{70}$

With these qualifications in mind, we turn to the current way in which the IRS monitors compliance with the private inurement constraint. The IRS already receives detailed annual reports from most section 501(c)(3) organizations containing information directly addressing the likelihood of private inurement. ${ }^{80}$ For these organizations the commercial manner inquiry is redundant. However, because of congressional and administrative concern about government agencies intruding into religious affairs, "churches, their integrated auxiliaries, and conventions or associations of churches"81 and "organizations operated, supervised, or controlled by or in connection with a church or convention or association of churches"82 are not required to file these annual reports.

When the IRS suspects that private inurement may be occurring in one of these non-filing religious organizations, it must begin its inquiry with little or no information about the organization's finances. ${ }^{83}$ However, as

78. If the commercial manner test is used as an independent test for exemption, religious nonprofits will be discouraged from adopting those commercial characteristics which are efficient for fear of losing their tax exemption. See, e.g., W. Bird, Publishing and Marketing Activities of Nonprofit Organizations: Tax Exemption and Unrelated Business Income Problems (unpublished manuscript presented to the Twenty-Second Annual Washington Non-Profit Tax Conference (Mar. 6-7, 1986)) (advising nonprofits to avoid assuming characteristics of commercial manner test).

79. For example, in Presbyterian \& Reformed Publishing Co. v. Commissioner, 743 F.2d 148 (3d Cir. 1984), the court, after determining that no private inurement was occurring, should not have looked for commercial purpose evidenced by a commercial manner of operation.

80. I.R.C. \$ $\$ 6033$ (1989). Exempt organizations are required to report gross income; expenses attributable to gross income; disbursements for exempt purposes; detailed information about assets, liabilities, and net worth; total amount of contributions and grants; names and addresses of all persons who contributed more than $\$ 5000$; names and addresses of all officers, directors, or trustees; names and addresses of the five employees receiving the greatest amount of annual compensation in excess of $\$ 30,000$; the total number of other employees who received annual compensation in excess of $\$ 30,000$; the names and addresses of the tive independent contractors (if any) who performed personal services of a professional nature for the organization and who received the greatest amount of compensation in excess of $\$ 30,000$ from the organization in the year; the total number of such independent contractors receiving in excess of $\$ 30,000$ for the year; and a schedule showing compensation and other payments includable in the gross income of each individual (who is required to be named under the previous standards) paid by the exempt organization. Treas. Reg. $\S 1.6033-2(a)(2)$ (ii)(a) to (h) (as amended in 1985).

81. I.R.C. $\$ 6033$ (a)(2)(A)(i) (1989). Because churches, their integrated auxiliaries, and conventions or associations of churches are not required to file for recognition of exemption under I.R.C. $\S 508$, the IRS may not even be aware that these organizations exist. Cerny \& Fotenrose, supra note 38 , at $\$ 1.03$.

82. Cerny \& Fotenrose, supra note 38 , at $\$ 1.03$ n.33. In addition, a church affiliated organization must meet an internal support test which it fails if it offers goods and services to the general public at prices that are not substantially below cost and normally receives more than $50 \%$ of its support from the government or the public, or from gross receipts from sales or services. Id.

83. Unless a non-filing organization is identified by high charitable deductions on a taxpayer's 
the Supreme Court emphasized in Walz, government involvement in religion should be minimized. ${ }^{84}$ Investigation of these organizations should therefore be minimally intrusive. Congress demonstrated its concern with overly intrusive government supervision of religious organizations in 1984 by restricting the Secretary of the Treasury's auditing of churches to determine eligibility for tax exemption. ${ }^{85}$

Both Supreme Court jurisprudence and congressional action emphasize the importance of making government intrusion into religion as narrow in scope and as infrequent as possible. However, the IRS needs to prevent tax-exempt church-related organizations from being operated to enrich individuals.$^{86}$ Under current law, when the IRS suspects that private inurement is occurring, it begins an inquiry attempting to trace all of the suspect organization's expenditures. Such inquiries reflect the intrusive questions non-church related organizations must answer in annual reports. $^{87}$

The important goal of minimizing government intrusion into religious affairs would be advanced by interposing the commercial manner test as a preliminary inquiry to assist in determining whether a full private inurement investigation is needed. Since the factors of the commercial manner test that indicate increased probability of private inurement are broad organizational characteristics, determining whether these factors exist requires a much less detailed inquiry than that needed to detect private inurement directly. The only information needed would be: 1) total revenues and total expenses for past and present years; 2) cash reserves; 3 ) a description of the type of religious activity in which the organization is engaged, sufficient to identify the existence of for-profit competitors; 4) assets and liabilities for past and present years; 5) number of paid and number of volunteer workers; and 6) number of persons in the controlling body of the organization. ${ }^{88}$

When the IRS suspects that a non-filing religious organization should not retain its tax-exempt status because private inurement is occurring, it

return, the IRS's decision to audit an organization is based on facts from taxpayer complaints, news articles, complaints by state attorneys general and other informal sources. 4 Internal Revenue Manual (Administration) (CCH) 7(10)75.2, at 22,411-31 (Mar. 17, 1988); Conversation with Professor John Simon, Member of the Advisory Committee on Exempt Organizations (Nov. 14, 1988).

84. Walz v. Tax Comm'n of the City of N.Y., 397 U.S. 664, 676 (1970) (tax exemption for churches "tends to compliment [sic] and reinforce the desired separation [of church from State] insulating each from the other").

85. Cerny \& Fotenrose, supra note 38 , at $\$ 1.03$. The IRS operates under the Secretary of the Treasury. Audits of churches may be conducted only when a high level Treasury official believes that the organization might not deserve exemption. Notice of the concerns giving rise to the audit is required before the audit may take place. The church has a right to a conference with the IRS before any examination of its records. Limits are imposed on the length of time that an audit may take and the frequency with which audits may be conducted. I.R.C. $\$ 7611$ (1989).

86. Sep supra notes 19-35 and accompanying text.

87. Ser supra note 80; see, e.g., Founding Church of Scientology v. United States, 412 F.2d 1197

(1969) (describing IRS private inurement investigation).

88. See supra Section III(B). 
should request that the organization make available data in these six categories. ${ }^{89}$ This data, based on broad organizational characteristics, should be evaluated in light of the analysis outlined in Section III. ${ }^{90}$ It should be used in conjunction with the other facts that originally drew the IRS's attention to a particular religious organization to determine whether an organization must be subjected to the intrusive private inurement inquiry. ${ }^{\text {11 }}$

\section{ConcLusion}

The IRS and the courts have used the commercial manner test as an independent test for tax exemption. This Note has argued that using the commercial manner test in this way is inconsistent with a rationale for religious exemption that is based on public benefit and that recrgnizes the need to prohibit private inurement. However, the IRS should use those factors of the commercial manner test that indicate increased probability of private inurement to help identify which religious organizations merit the intensive scrutiny of a full private inurement investigation. This approach would further the important goal of minimizing government involvement with religion.

89. If the non-filing organization claims church status, invoking the provisions of I.R.C. $\$ 7611$, the appropriate time to request this data is when notice of a tax inquiry (first notice) is served on the church. See supra note 85 and accompanying text. I.R.C. $\S 7611$ (a) requires formal written notice to an organization claiming to be a church before an inquiry into eligibility for tax exemption may be made. I.R.C. § 7611(a) (1989); see also Treas. Reg. § 301.7611-1 (1986). If the organization falls under the provisions of I.R.C. $\S 7611$, this information should be used to assist in determining when a notice of examination (second notice) should be issued. Issuance of a notice of examination precedes the formal conference requirements of I.R.C. $\$ 7611$ and indicates that a detailed investigation of church records is imminent. I.R.C. \$ 7611(b) (1989); Treas. Reg. \$ 301.7611-1 (1986).

90. IRS compliance with this two-step investigative structure could be enforced by allowing the monitored religious organization to appeal the IRS's request for further information (after conducting the modified commercial manner inquiry) to a court. However, it would seem that a test attempting to measure increased probability that an illicit activity is occurring would be best applied by agency officials with an accumulated body of expertise. In addition, many monitored religious organizations, especially those with nothing to hide, might find it easier to disclose the requested information than to seek relief in court. Thus, the harm of intrusive government regulation of religion would not be prevented.

These considerations suggest that the best approach to ensuring IRS compliance with this new monitoring scheme would be one which prevents the IRS from making unwarranted requests for financial disclosure. Weingast and Moran's study, linking Federal Trade Commission behavior to the preferences of the relevant congressional oversight committees, suggests that informal congressional controls might achieve this end. Weingast \& Moran, Bureaucratic Discretion or Congressional Control? Regulatory Policymaking by the Federal Trade Commission, 91 J. PoL. Econ, 765 (1983); sfe also J. Mashaw \& R. Merril., Administrative Law 110-72 (2d ed. 1985) (reviewing executive supervision of administrative action). Legislative and executive control of the IRS in such a politically volatile area is likely.

91. An alternative proposal, consistent with the analysis of this Note, is that Congress should change the annual reporting requirements for religious organizations. Those that are currently nonfilers could be required to file annual returns containing the six points of information outlined abave. See supra text accompanying note 88. This would allow the IRS to detect situations where there is an increased likelihood of private inurement without the detailed reporting required of most $\S 501(c)(3)$ organizations. See supra note 80 . This solution would, however, imply greater intrusion by the government into religious organizations. 